\title{
Overexpression of metallothioneins, stem cell niches and field cancerization in experimental gliomagenesis
}

\author{
A superexpressão de metalotioneínas em células-tronco de áreas \\ cancerígenas na gênese de glioma experimental
}

Superexpresión de metalotioneínas, nichos de células madre y campos de cancerización en gliomagénesis experimental

\author{
Julio César Fernandes da Silva ${ }^{1}$ \\ Vinicius Kanen Cardoso' \\ Aline Turatti ${ }^{1}$ \\ Alfredo Ribeiro-Silva ${ }^{2}$ \\ Carlos Fernando Pereira da Silva Herrero ${ }^{3}$ \\ Sergio Britto Garcia ${ }^{2}$
}

\section{ABSTRACT}

Introduction: stem cells may originate and perpetuate the tumor growth, but they are poorly known in gliomagenesis. Metallothioneins (MTs) are proteins involved in oncogenesis and immunopositivity, for MT may be used as a stem cell mutation marker. Objective: to study the MT expression in the ENU experimental model and to establish an experimental model to track glioma stem cells in early oncogenesis. Methods: Thirtysix male Wistar rats were divided into two groups; the experimental group was treated within 24 hours after birth (neonate rats) with a single dose of subcutaneously injected N-ethyl N-nitrosourea ENU $(40 \mathrm{mg} /$ $\mathrm{kg}$ body weight). The control animals were injected with the same volume of saline. These experimental animals were subdivided into three groups according to the euthanize time, as follows: the Group 1 (G1) was euthanized at the age of 30 days; the Group

\section{RESUMO}

Introdução: células-tronco podem originar e perpetuar o crescimento tumoral, porém são pouco conhecidas na gliomagênese. As metalotioneinas (MTs) são proteínas envolvidas na oncogênese, e sua a imunopositividade pode ser utilizada como marcador de mutação de células-tronco. Objetivo: estudar a expressão de MT no modelo experimental da ENU e estabelecer um modelo experimental para monitorar as células-tronco glioma na oncogênese. Métodos: Trinta e seis ratos machos da raça Wistar foram divididos em dois grupos; o grupo de animais experimental foi tratado dentro de 24 horas após o nascimento (ratos neonatos) com uma dose única de $N$-etil $N$-nitrosoureia (ENU) $(40 \mathrm{mg} / \mathrm{kg})$. Nos animais do grupo controle, injetou-se o mesmo volume de solução salina. Os animais do grupo experimental foram subdivididos em três grupos de acordo com o tempo da eutanásia, como se segue: o Grupo 1 (G1) sofreu eutanásia com a idade de

\section{RESUMEN}

Introducción: células madre pueden originar y perpetuar el crecimiento tumoral, sin embargo son poco conocidas en la gliomagénesis. Las metalotioneinas (MTS) son proteinas involucradas en la oncogénesis, y la inmunopositividad de las MTs puede ser utilizada como marcador de mutación de las células madres. Objetivo: estudio de la expresión de MT en el modelo experimental de la $N$-etil N-nitrosoureia (ENU) y establecer un modelo experimental para el seguimiento de las células madre en la oncogénesis glioma. Métodos: treinta y seis ratas machos Wistar fueron divididas en dos grupos, un grupo de animales experimentales fue tratado dentro de 24 horas después del nacimiento (ratas neonatas) con una dosis única de ENU (40 $m g / k g)$. Los animales del Grupo Control fueron inyectados con el mismo volumen de solución salina. Los animales del Grupo Experimental fueron subdivididos en tres grupos de acuerdo con el tiempo de eutanasia, así como sigue: el

\footnotetext{
Trabalho realizado no Departamento de Patologia da Faculdade de Medicina de Ribeirão Preto da Universidade de São Paulo - USP - Ribeirão Preto (SP), Brasil.

'Pós-graduando do Departamento de Patologia da Faculdade de Medicina de Ribeirão Preto da Universidade de São Paulo - USP - Ribeirão Preto (SP), Brasil. 2Doutor; Professor do Departamento de Patologia da Faculdade de Medicina de Ribeirão Preto da Universidade de São Paulo - USP - Ribeirão Preto (SP), Brasil. ${ }^{3}$ Pós-graduando do Departamento de Biomecânica, Medicina e Reabilitação do Aparelho Locomotor do Hospital das Clínicas da Faculdade de Medicina de Ribeirão Preto da Universidade de São Paulo - USP - Ribeirão Preto (SP), Brasil.
} 
2 (G2), at the age of 180 days and the Group 3 (G3) was euthanized soon after the appearing of signs of the existence of nervous system tumors, at an average age of 321 days. Immunohistochemical detection of MT protein in cold acetone-fixed paraffin embedded spine cord sections was performed by the streptavidin-avidinbiotin-immuno peroxidase complex method. Results: by using the experimental model of gliomagenesis induced by the $\mathrm{N}$-ethyl $\mathrm{N}$-nitrosourea, it was possible to detect putative tumor stem cells in early oncogenesis, to analyze a field cancerization process and to observe a close morphological relationship between MT positive cells and blood vessels. Conclusions: this reproducible experimental model allows further studies on the origins, development and regulating factors involved in gliomagenesis.
30 dias; o Grupo 2 (G2), com 180 dias e o Grupo 3 (G3) sofreu eutanásia logo após o surgimento de sinais de existência de tumor do sistema nervoso, com uma média de idade de 321 dias. A detecção imunohistoquímica da proteína MT em cortes da medula espinhal fixadas em acetona fria e embebidas em parafina foi realizada pelo método do complexo streptavidina-avidina-biotina-imuno peroxidase. Resultados: por meio de modelos experimentais de gliomagenese induzida pela $N$-etil $N$-nitrosoureia, foi possivel detectar células-tronco de tumor putativo no início da oncogênese, analisar um processo de cancerização de campo e observar uma relação morfológica entre células positivas para MT e vasos sanguineos. Conclusões: este modelo experimental reprodutivel permite outros estudos sobre a origem, desenvolvimento e fatores reguladores da gliomatogênese.
Grupo G1 sufrió eutanasia con la edad de 30 días; el Grupo G2, con 180 días y el Grupo G3, después del surgimiento de señales de existencia de tumor del sistema nervioso, con un promedio de edad de 321 días. La detección inmunohistoquímica de la proteína MT en cortes de médula espinal fijados en acetona fría y embebidos en parafina fue realizada por el método del complejo estreptovidinaavidina-biotina-inmuno peroxidase.

Resultados: por medio de modelos experimentales de gliomagénesis inducida por la ENU fue observado que es posible detectar células madre de tumor putativo en el inicio de la oncogénesis, para realizar un proceso de cancerización de campo y observar una relación morfológica entre células positivas para MTy vasos sanguineos. Conclusión: este modelo experimental reproductible permite otros estudios involucrando el origen, desarrollo y factores reguladores de la gliomatogénesis.

DESCRIPTORES: Glioma; Metalotioneína; Células madre
KEYWORDS: Glioma;

Metallothionein; Stem cells
DESCRITORES: Glioma;

Metalotioneína; Células-tronco 
groups of treatment at study completion. The animals were maintained in agreement with the guidelines of the Committee on Care and Uses of Laboratory Animals from the National Research Council of the NIH (USA). The experimental group was treated within 24 hours after birth (neonate rats) with a single dose of subcutaneously injected ENU ( $40 \mathrm{mg} / \mathrm{kg}$ body weight $)^{6}$. The control group animals were injected with the same volume of saline.

\section{Experimental design}

The animals were divided into six groups of six animals. The experimental groups were injected with ENU, as previously mentioned. These animals were subdivided into three groups according to the euthanasia time, as follows: the group 1 (G1) was euthanized at the age of 30 days; the group 2 (G2), at the age of 180 days and the group 3 (G3) was euthanized soon after the appearance of signs of the existence of nervous system tumors, at an average age of 321 days. The control groups were euthanized at equivalent ages of the experimental groups. They were named $\mathrm{C} 1, \mathrm{C} 2$ and $\mathrm{C} 3$, respectively.

At the respective time points, all experimental animals were euthanized by carbon dioxide asphyxiation and submitted to a complete necropsy. Spinal cords were fixed in $10 \%$ buffered formalin. All lesions and six selected segments of spinal cord were embedded in paraffin, sectioned and stained with hematoxylin and eosin (H\&E) for pathologic evaluation of tumors. The paraffin-mounted serial sections of the rat's spinal cord were used for MT immunohistochemistry staining. Immunohistochemical detection of MT protein in cold acetone-fixed paraffin embedded spine cord sections was performed by the streptavidin-avidin-biotin-immuno peroxidase complex method, as previously described ${ }^{5,7}$. Two investigators (SB Garcia and Vinicius) independently evaluated the immunohistochemistry. Both observers were blind to the identification of groups. MT immunostaining was considered positive when the nuclei and cytoplasm of the nervous tissue cells were prominently stained (purplish brown/reddish brown). The pattern of MT staining was also characterized as cytoplasmic only, nuclear only, and both cytoplasmic and nuclear. MT positive cells were quantified per microscopic field. A total of 10 high power (40x) fields were randomly chosen. The number of positive vessels was evaluated per $\mathrm{mm}$ of the spinal cord surface length.

The tissue sections of spinal cord stained with immunohistochemistry were divided into three areas: A1, subpial region (a $50 \mu \mathrm{m}$ thick margin from the pia matter); $\mathrm{A} 2$, the nervous tissue parenchyma, including white and gray matter; and A3, area surrounding the central canal of the spinal cord. Five slides representing each animal were evaluated for each study. Only spinal cord tissue with normal appearance was considered for the study of the Groups C1, G2, C3, G1 and G2. For the A2 first study evaluation, five microscopic fields at medium-power (40x) were randomly taken from different sites on each immunostained tissue section and up to two blocks used from the same animal taken from different regions of the spinal cord.

Data were statistically analyzed by the ANOVA test. Differences were considered to be significant when $p \leqslant 0.01$.

\section{RESULTS}

Apart from the G3, all animals remained in good health and none showed clinical signs of nutritional deficiency during the experimental period. At the end of the experiment, the average weight of all animals did not differ between the groups at the same time point. In G3, clinical signs of spinal cord involvement developed over a period of days to weeks. Most commonly, a unilateral posterior paresis was followed by bilateral paralysis. In these animals, tumors were located most frequently in the lower thoracic and lumbar regions of the spinal cord. Hematoxylin and eosin staining of paraffin-embedded tumors have shown the presence of nodular lesions mainly in the white matter of the spinal cord (not shown). At a higher magnification, the nodules consisted of well differentiated oligodendrogliomas. The neuroepithelial origin of the tumors was confirmed by the GFAP immunostaining, that was positive in all lesions, and leucocyte common antigen (LCA) negative (data not shown). All tumors showed a biphasic pattern consisting of round and weakly MT stained cells in small number in the tumor core, and a number of spindle highly stained MT-positive cells surrounding the tumors and their desmoplastic stroma (Figure 1A). We named these cells Metallothionein-OverExpressing-Cells (MTOEC). The METOC were lined with the tumor boundaries at their surface, contacting the apparently normal surrounding tissue (Figure 1B). In the MTEOC, the immunohistochemical localization of MT was demonstrated in both the cytoplasm and the nuclei of the apparently normal nervous tissue cells and in the tumors (Figure 1B), whereas in the control animals the MT staining was present in a small number of round cells, with a considerably weaker attaining and localized only in the cytoplasm (Figure 1C). The control animals did not show the presence of MTOEC in any of the three evaluated regions of the spinal cord.

In the ENU-treated groups G1 and G2, MTEOC were also found. These cells were very similar to those found in the tumors boundaries $(\mathrm{G} 3)$. In the G1, the MTEOC were found only in the subpial region, with no strong MT staining in the other assessed spinal cord regions. The MTEOC were also observed in the subpial region of the spine cord of the G2 animals (Figure 1D), and the frequency of MTOEC was approximately twice higher than that of G1 animals $(23.9 \pm 1.9$ and $12.3 \pm 1.2$ cells per histological section, respectively; $p<0.01$, ANOVA test). Furthermore, in G2 animals, scattered islands with groups of MTEOC were seen, as well as blood vessels acquiring MT positivity at their peripheral zone facing the endothelium, and some positive cells were found not only in the subpial region (Figure 1D). 



Figure 1

Spinal cord of rat immunostained for metallothioneins (MT). (A) Higher magnification of boxed area in (B). Note the highly MT stained cell (MTEOC) situated in niches that are only located in the peri-vascular area; (B) Presence of metallothionein-positive cells in a small oligodendrioma 321 days after ENU treatment. Note the presence of highly positively stained cells (MTEOC) in the neighboring area of the tumor (arrows); (C) Weak immunoreactivity for metallothionein in isolated cells of the spinal cord of a normal control animal (arrows); (D) A large number of MT-positive cells (black arrows) are found at the subpial region of the spinal cord 180 days after ENU treatment. Most of the MT-positive cells are near vessels. Some MTEOC are seen deeper in the spinal cord parenchyma, far from the subpial region (white arrow).

\section{DISCUSSION}

Glioma is the most common primary tumor of the brain, but very little is known about the processes through which it develops. It is useful and necessary to have animal models for the existing central nervous system tumors that allow studies to be carried out in different stages of growth, especially in the early stages, that are difficult to be observed in clinical practice ${ }^{8}$. To the best of our knowledge, MT expression had not been studied in experimental models of gliomas yet. This paper showed that the administration of a mutagen to one-dayold rat leads to the formation of scattered subpial MT positive cells after 30 days, and that the frequency of these cells is (a) strongly correlated with the increased appearing of early neoplastic proliferation (ENP) centers and new blood vessels, (b) is augmented at higher levels in long-term observation, 180 days after the carcinogen administration, (c) is related to a high staining intensity in both nucleus and cytoplasm, and (d) is very similar to the pattern of immunostaining that was observed in the nervous tissue surrounding the gliomas, which were originated at an average of 321 days after the ENU administration.

In the normal nervous tissue, the MT expression has generally been associated with heavy metal detoxification, intracellular trace elements storage and scavenging of free radicals. An increased expression of MT is normally associated with exposure to stress and inflammation. In these circumstances, expression in the tissues is diffuse and short-lived, returning to baseline levels approximately 20 hours after the exposure of an inflammatory stimulus ${ }^{9}$. The ENU induced over expression of MT 
(MTOEC) in our findings is clearly different because (a) it is highly and specifically restricted to the subpial area of the spinal cord, at the same location of putative target cell in the ENU carcinogenesis model ${ }^{6}$ and (b) the staining pattern of the affected cells is far more intense, affecting both cytoplasm and nucleus, than the eventual findings in positive cells of control animals or in the inflammatory stimulated MT expression, as reported in the literature ${ }^{10}$.

The MTOEC herein described are similar to the previously described MTOEC that spread in the colon and liver of mouse treated with a single dose of carcinogen $^{5,11}$. In both organs, the MTOEC are considered to be useful positive markers for stem cells in preneoplastic lesions ${ }^{12}$, though the mechanisms and reasons why MT is overexpressed in these cells remain to be elucidated. It has been hypothesized that mutation-induced MT overexpression may interfere with the function of zinc finger DNA binding transcription factors, which have been implicated in transcriptional control of various genes, including p53, involved in cell proliferation and apoptosis ${ }^{13}$. These MT-mediated effects on gene transcription are thought to confer a selective growth or survival advantage (or both) on the mutated cells ${ }^{13}$. The vast majority of the MTOEC in our study expressed MT in both cytoplasm and nucleus of ENU-treated animals, what strongly suggests that these MTOEC are mutant cells, as reported in other studies ${ }^{5}$. Regardless the causes and consequences of this over-expression of MT, if one assumes that MTEOC are mutant stem cells, it may provide a new way to track mutated stem cells. It is thought that stem cells live in protected pockets of the body called niches, where they divide infrequently to avoid accumulating damaging mutations. Upon injury or in response to normal stimuli, stem cells are mobilized to divide ${ }^{14}$. Parallel to the role that normal stem cells play in organogenesis, stem cells are thought to be crucial for tumorigenesis.

The existence of a number of mutated MTOEC that spread in the nervous tissue of carcinogen-treated animals fits well in the "field cancerization theory". We had previously discussed that, according to this theory, a stem cell acquires genetic alterations and forms a "patch", a clonal unit of altered daughter cells ${ }^{15}$. The proliferation of these patch cells forms expanding fields which gradually displace the normal tissue and by clonal divergence ultimately leads to the development of one or more tumors within a contiguous field of preneoplastic cells. The field cancerization theory implies that the mutated genotype and molecular changes occur before the appearance of histopathological evidence of malignant cells ${ }^{15}$. An important clinical implication is that fields often remain after primary tumor surgery and may lead to new cancers, designated presently by clinicians as "a second primary tumor" or "local recurrence", depending on the exact site and time interval ${ }^{16}$.
The main practical problem is how to identify, mark and track the cancerization fields. Based on our findings and on the literature considerations, we suggest that MT staining is a candidate to such task.

Neural stem cells arise from a region called radial glia (RG) within the central nervous system and the RG cells produce neurons in addition to glia during central nervous system development in all vertebrates and are also involved in reparative process ${ }^{17}$. Comparing the gene expression profiles of ependymomas to those of cells in the normal developing nervous system, it was possible to pinpoint the RG cells as candidate stem cells of this brain tumor ${ }^{14}$. Our data adds great support to this hypothesis, since the main location of the ENU-induced MTOEC herein described present striking similarity to the radial glia cells; however, this relationship needs further detailed investigation.

Furthermore, our results clearly show the existence of a close morphological relationship between MTOEC and blood vessels. But what is the functional relationship between them? It is known that MT is involved in the regulation of the functions of endothelial cells, as well as in their protection against cytotoxic agents $^{18}$. MT knock-out (MT-KO) mice presented dramatically decreased IL-6-induced angiogenesis caused by cortical freeze injury, suggesting that the MT have major regulatory functions in the angiogenesis process $^{10}$. Interestingly, recent data suggest that stem cells of glioblastoma are situated in close proximity to endothelial cells and seem to be dependent on cues from aberrant vascular niches that mimic the normal neural stem cell niche, facilitating communication between these cell types, what may influence the stem cell regulation ${ }^{19,20}$. Supported by our findings, we suggest that MT may play a role in such relationship, which warrants further investigation. A recent review article on gliomagenesis addresses the following key question: are cancer stem cell niches the primary drivers of tumor development, or are they recruited by pre-formed cancer stem cells? ${ }^{19}$ From our findings, it is possible to suggest that the second option is more likely to occur, since we have observed a higher number of isolated MTOECs at 30 days after ENU injection than after 180 days. At this last time point, most of the MTOECs are located in close relationship to endothelial cells, suggesting that MTOEC may induce angiogenesis around then.

Finally, we and other authors have shown that the amount of MT overexpressing cells correlates well with factors that are known to influence colon carcinogenesis, such as the non-steroidal anti-inflammatory drugs and $\operatorname{diet}^{4,7}$. In case this occurs in the glia, the MT staining may provide a simple and reliable method to design short-term studies to verify factors that could influence gliomagenesis, by evaluating the number of MTOEC formation and proliferation. It must be pointed out that putative risk 
factor for gliomas are currently poorly known, at least partially because of a lack of feasible and reliable experimental models to test then, as there are largely available methods to study oncogenesis modulator factors in other organs. In conclusion, we developed a reproducible model for marking and quantifying putative mutant stem cells related to gliomagenesis, allowing further studies on their origins, development and regulating factors.

\section{ACKNOWLEDGEMENTS}

Part of this work was supported by Coordenação de Aperfeiçoamento de Pessoal de Nível Superior (CAPES), Conselho Nacional de Desenvolvimento Científico e Tecnológico $(\mathrm{CNPq})$, and Fundação de Amparo à Pesquisa do Estado de São Paulo (FAPESP) (grant 2001/14227-0). The authors would like to thank Mrs. R.O. Lopes for his expert technical assistance

\section{REFERENCES}

1. Sanchez-Martin M. Brain tumor stem cells: implications for cancer therapy and regenerative medicine. Curr Stem Cell Res Ther. 2008;3(3):197-207.

2. Thirumoorthy N, Manisenthil Kumar KT, Shyam Sundar A, Panayappan L, Chatterjee M. Metallothionein: an overview. World J Gastroenterol. 2007;13(7):993-6.

3. Hiura T, Khalid H, Yamashita H, Tokunaga Y, Yasunaga A, Shibata S. Immunohistochemical analysis of metallothionein in astrocytic tumors in relation to tumor grade, proliferative potential, and survival. Cancer. 1998;83(11):2361-9.

4. Donnelly ET, Bardwell H, Thomas GA, Williams ED, Hoper M, Crowe $\mathrm{P}$, et al. Modulation of N-methyl-Nnitrosourea-induced crypt restricted metallothionein immunopositivity in mouse colon by a non-genotoxic diet-related chemical. Carcinogenesis. 2004;25(5):847-55.

5. Cook AH, Williams D, Thomas AG. Crypt-restricted metallothionein immunopositivity in murine colon: validation of a model for studies of somatic stem cell mutation. J Pathol. 2000;191(3):306-12.

6. Naito M, Naito Y, Ito A, Watanabe H, Kawashima K. Spinal cord tumors induced by N-ethyl-N-nitrosourea in rats: presence of spinal subpial target cells. J Natl Cancer Inst. 1984;72(3):715-24.

7. Escalante RD, de Oliveira EC, Cunha FQ, Vespúcio MV, Ribeiro-Silva A, Aprilli F, et al. Trypanosoma cruzi infection and the non-steroidal anti-inflammatory Nimesulide increase metallothionein over expressing colonic crypts in rat colon carcinogenesis. Braz J Med Biol Res. 2006;39(7):895-9.
8. Bulnes-Sesma S, Ullibarri-Ortiz de Zárate N, Lafuente-Sánchez JV. [Tumour induction by ethylnitrosourea in the central nervous system]. Rev Neurol. 2006;43(12):733-8. Spanish.

9. Bremmer I. Nutritional and physiologic significance of metallothionein. Methods Enzymol. 1991;205:25-35.

10.Penkowa M, Carrasco J, Giralt M, Molinero A, Hernández J, Campbell IL, et al. Altered central nervous system cytokine-growth factor expression profiles and angiogenesis in metallothionein-I+II deficient mice. J Cereb Blood Flow Metab. 2000;20(8):1174-89.

11. Chakraborty T, Chatterjee A, Rana A, Srivastawa S, Damodaran S, Chatterjee M. Cell proliferation and hepatocarcinogenesis in rat initiated by diethylnitrosamine and promoted by phenobarbital: potential roles of early DNA damage and liver metallothionein expression. Life Sci. 2007;81(6):489-99.

12.Sawaki M, Enomoto K, Hattori A, Tsuzuki N, Sawada N, Mori M. Elevation of metallothionein level in preneoplastic lesions during chemical hepatocarcinogenesis of the Fischer 344 rat. Toxicol Lett. 1999;108(1):5561.

13.Bruewer M, Schmid KW, Krieglstein CF, Senninger N, Schuermann G. Metallothionein: early marker in the carcinogenesis of ulcerative colitisassociated colorectal carcinoma. World J Surg. 2002;26(6):726-31

14. Gilbertson RJ. Brain tumors provide new clues to the source of cancer stem cells: does oncology recapitulate ontogeny? Cell Cycle. 2006; 5(2):135-7.
15.Garcia SB, Park HS, Novelli M, Wright NA. Field cancerization, clonality, and epithelial stem cells: the spread of mutated clones in epithelial sheets. J Pathol. 1999;187:61-81.

16.Braakhuis BJM, Tabor MP, Kummer JA, Leemans CR, Brakenhoff RH. A genetic explanation of Slaughter's concept of field cancerization: evidence and clinical implications. Cancer Res. 2003;63(8):1727-30.

17. Weiner LP. Definitions and criteria for stem cells. Methods Mol Biol. 2008;438:3-8.

18.Kaji T, Yamamoto C, Tsubaki S, Sakamoto M, Sato M, Kozuka $\mathrm{H}$. Metallothionein induction by cadmium, cytokines, thrombin and endothelin-1 in cultured vascular endothelial cells. Life Sci. 1993;53(15):1185-91.

19.Gilbertson RJ, Rich JN. Making a tumour's bed: glioblastoma stem cells and the vascular niche. Nat Rev Cancer. 2007;7(10):733-6.

20.Scadden, DT. The stem-cell niche as an entity of action. Nature. 2006;441:1075-9.

\section{Correspondência}

Sergio Britto Garcia

Departamento de Patologia da Faculdade de Medicina de Ribeirão Preto da Universidade de São Paulo

Avenida Bandeirantes, 3.900

CEP 14048-900 - Ribeirão Preto (SP), Brasil

E-mail: sbgarcia@fmrp.usp.br 